New spiders from southern New England. Psyche, XXXI, 140-145, 1924.

New Californian spiders. Pan Pacific Entom, I, 29-31, 1924.

Spiders from the Lake Abitibi Region. Univ. Toronto Studies, Biol. Ser. No. 32, 45-46, 1928.

Spiders of Nantucket. 4 pp. sep. publ., 1930.

Spiders of Nantucket. Nantucket Maria Mitchell Assoc., III., No. 2, 161-172. 1930.

\title{
BIOLOGICAL NOTES ON CUBAN WASPS AND THEIR PARASITES
}

\section{BY RICHARD DOW}

The material for the following notes was collected in Cuba during August and September, 1930. Through a scholarship from the Atkins Foundation, I was enabled to spend nearly five weeks at the Harvard Biological Laboratory near Cienfuegos, Santa Clara. The laboratory is located on the Atkins sugar estate, Central Soledad, and the situation is ideal for this sort of work.

I wish to thank the following people who have assisted me by determining material: Professor Nathan Banks, Mr. H. S. Barber, Dr. A. G. Böving, Miss E. B. Bryant, Mr. R. A. Cushman, Mr. Carl Heinrich, and Mr. J. A. G. Rehn. I am also indebted to Mr. S. C. Bruner of Santiago de las Vegas, Cuba, for permission to publish his observation on Chlorion cubensis, and Professor Joseph Bequaert, who has read my manuscript and identified all of the Vespidæ. Although the synonymy of these wasps is more or less tangled, I am using the names which will soon appear in a work on the West Indian Vespidæ by Dr. Bequaert and Dr. George Salt.

\section{Chlorion (Ammobia) dubitatum (Cress.)}

I found several nests of this species in a shallow clay pit near Belmonte, Central Soledad. They consisted of a 
vertical shaft, ten or more centimeters deep, and a sloping tunnel, five or six centimeters long, which ended in a single cell. I found extra cells in only one nest, but there may have been several cells in each burrow, which I failed to find because the tunnels were stopped up.

In all the completed cells, the larvæ had spun their cocoons, leaving only a few chitinous fragments of the prey, such as wings, legs, and ovipositors. From an examination of these remains, Mr. J. A. G. Rehn was able to assign them to Conocephalus sp.

The cocoon is composed of three layers. The whitish outer layer is yellowish at the apex, finely woven, and transparent; the middle layer is a thicker envelope of the same material; the brown inner layer is closely associated with the middle envelope and probably formed of some waste secretion. The meconium is apparently voided within the inner layer, and its concave upper surface is smooth and shining like the inside of the cocoon.

In the four adult females which I caught at this locality, none of the abdominal segments are wholly black, and only traces of the typical black coloration remain.

\section{Chlorion (Ammobia) cubensis Fern.}

Mr. S. C. Bruner found this species with a paralyzed long-horned grasshopper at Sante Fé, Isla de Pinos, September 6, 1928. The grasshopper, determined by Mr. J. A. G. Rehn, was a mature female of Neoconocephalus maxillosus (Fabr.). The wasp was dragging its prey through open piney woods. It was holding the fore part of the grasshopper's body and walking backwards. Mr. Bruner watched the wasp climb the trunk of a tree, still pulling its prey behind it, until it reached a height of about two meters. The wasp and grasshopper were then captured. This suggests a similar habit of Sphecius speciosus (Drury), which preys on cicadas. When Sphecius is taking a heavy cicada to its burrow, it frequently drags its prey up a tree, and then, taking advantage of the height attained, flies directly to the nest. 


\section{Sceliphron assimile (Dahlb.)}

This species and Sceliphron cæmentarium are very closely related, and the nests are found in similar places. The nests of assimile are common in Soledad; one lot was taken from the palm thatching of a house near Vilches Potrero, and another from the walls of the buildings at the main entrance of the estate.

The prey of this species consists entirely of spiders. Some of the prey from these nests was identified by Miss E. B. Bryant as follows: a large number of Epeiridæ represented by males and females of Epeira oaxacensis Keys. and Epeira fuscovittata Keys., mostly immature and mostly oaxacensis; a few Thomisidæ represented by immature and adult females of Misumena sp.; one adult female of the Sicariidæ, Scytodes sp.; and one immature male of the Attidæ, Phidippus sp.

A few spiders were also collected from nests of Sceliphron in the lighthouse at Punta de los Colorados, near Cienfuegos, on September 4. Since Sceliphron assimile is the only species of Sceliphron which I found in that locality, these spiders were probably stored by that species. The prey was determined by Miss Bryant as follows: a small number of immature Oxyopidæ represented by males and females of Peucetia viridans (Hentz); two adult Epeiridæ, females of Epeira prompta Hentz; and two adult Clubionidæ, a male and female of Chiracanthium inclusum (Hentz).

The cocoon of assimile is approximately cylindrical, rounded at the apex, and narrowed toward the posterior end. I found one larva which had died after spinning the silken foundation of its cocoon. I cannot be certain that this is complete at the posterior end of the larva, and I am inclined to believe that the meconium is a true stercoral plug, which is excreted after the cocoon is finished. Before the larva begins its resting period, it also secretes a substance which colors the cocoon yellowish brown and makes it brittle in texture. When the mature wasp is about to emerge, it bites an irregular hole in the side of the 
cocoon near the top, then softens the clay with a liquid secreted from the mouth. The adult also excretes some tiny white elongate pellets, presumably from the anus. This is the fifth distinct excretory or secretory product, the others being the silken part of the cocoon (from the mouth), the meconium or stercoral plug (from the anus), the excretion or secretion which permeates the silk (from the mouth ?), and the secretion which softens the clay cell.

Associated with Sceliphron assimile were an ichneumonid parasite, a dermestid beetle, and a vespid inquiline, Pachodynerus nasidens (Latr.). The ichneumonid is Acroricnus cubensis (Cress.) [R. A. Cushman]. When Cresson described this species, he noted that it was "parasitic upon the larva of Pelopœeus lunatus Fab." Later on in the same work (On the Hymenoptera of Cuba), he lists P. lunatus as a synonym of $P$. cæmentarius. I have not seen any typical specimens of Sceliphron cæmentarium from Cuba, so Cresson probably considered $S$. assimile as that species.

The cocoon of Acroricnus cubensis is obconical, whitish or yellowish in color, fuzzy outside and smooth within. The meconium is excreted inside the cocoon and is therefore not a true stercoral plug. Sometimes a rudimentary cocoon is formed within that of the Sceliphron, indicating that these larvæ did not gain ascendency over their host until the resting period of its larva. In these examples, the rounded apex of the cocoon is somewhat below that of the host cocoon and attached to its wall. Between the apex and the conical posterior end which is attached in a similar way, there is no apparent indication of any cocoon spun by the parasite.

The dermestid beetles which I found in the nests of Sceliphron assimile were determined as Trogoderma sp. [A. G. Böving (larvæ), H. S. Barber (adults)]. The mature specimens are identical with a form reared by J. C. Bridwell from a package of seeds of Sophora stored at Brownsville, Texas, in 1921. Mr. Barber's note is interesting in this connection. "Several other forms of Trogoderma have been reared from cells of mud wasps about buildings and seem to reflect no other connection with these 
nests than might be expected from the well-known food habits of larvæ of this genus. In the other cases, and probably also in the present instance, it is supposed they chanced to be attracted to the dried animal matter in unsuccessful cells, from a nearby infestation in other material. Attempts to identify the very numerous and usually misdetermined species of this ubiquitous genus have proven very unsatisfactory because a number of species infesting the personal or household effects of colonists or travelers have become established wherever conditions permitted survival, and have received an excessive number of names, associated with misleading or inadequate 'descriptions' to which have been added a great number of records under wrongly applied specific names."

\section{Pachodynerus nasidens (Latr.) [J. Bequaert]}

The nests of this vespid were found in the cells of Sceliphron assimile. It is apparently a true inquiline, using only the deserted cells of its host. It makes two or more cells out of each one of assimile by constructing thin, horizontal partitions of mud, and fills the cells with a species of lepidopterous larva belonging to the Pyraustinæ of the Pyralidæ [Carl Heinrich]. The egg is suspended by a delicate thread. There is no true cocoon, but the larva covers the walls of its cell with a shining, transparent, yellowish layer of silk, occasionally stretching this membrane across the corners.

\section{Polistes incertus Cress. [J. Bequaert]}

The entrance to Cienfuegos Bay is a narrow channel about three miles long, which gradually widens toward the sea. Near Punta de los Cocos on the western side, the shore is bordered by thickets of sea grape (Coccoloba), inhabited by the Giant Land Crab (Cardisoma guanhumi Latr.). Farther inland the sea grape is replaced by mixed second growth, in which I found a single nest of Polistes incertus, on September 3. The nest was hanging from a 
twig about two meters above the ground. When I disturbed the wasps, they flew away, so I broke off the twig and found, upon examining the nest, that all the cells were empty. This fact probably accounts for the readiness with which the wasps took flight. Hoping they would return, I came back later in the afternoon; with better success than before, I captured a total of sixteen specimens.

In addition to these individuals (9 workers and 7 males), I collected two stray queens; one was taken at Castillo de Jagua on September 5, and the other at Limones Seboruco, Soledad, on September 15. The sexual dimorphism of the female sex is very marked, as may be seen in the following table, where the total length of the head, thorax, and first two tergites of the abdomen is given in millimeters :

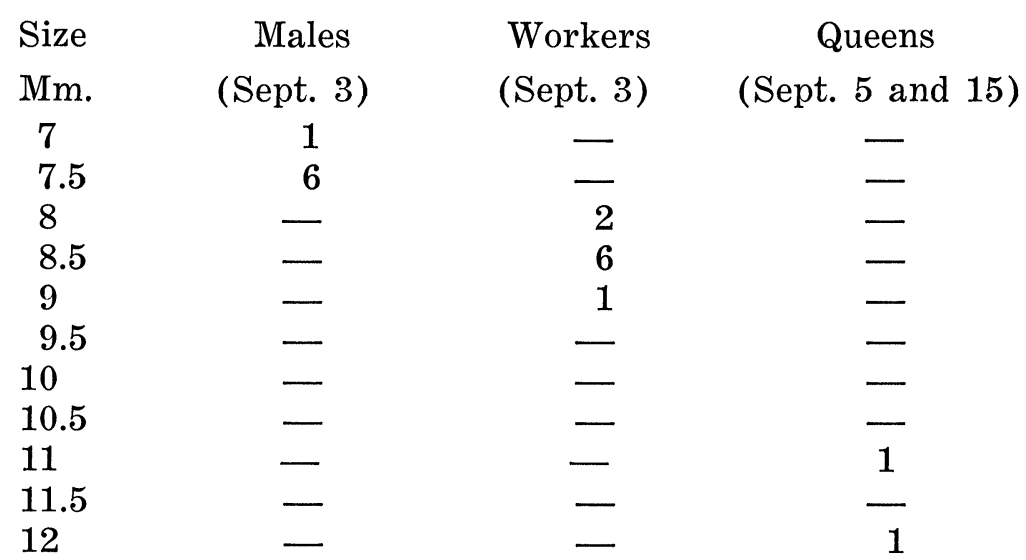

Two of the above specimens were stylopized: one of the $7.5 \mathrm{~mm}$. males had one parasite under the left side of the fifth tergite, and one of the $8.5 \mathrm{~mm}$. workers had one parasite under the left side of the fourth tergite and one parasite under the right side of the fifth tergite.

The nest of Polistes incertus was previously unknown. The present example (see plate 1, figures 1 and 2 ) is fastened to the twig by a single attachment at the base of the uppermost cells. The comb hangs in a vertical plane, but 
most of the cells are directed downward instead of being horizontal. The comb is irregular in outline, and somewhat curved so that the bases of the cells form a concave surface. The length of the comb is about seven centimeters, and the average width is less than four. There are 227 cells, about thirty of which are incomplete. Some of the cells in the middle of the comb are distinctly deeper than the others, and were probably occupied by the young queens. As previously noted, there were no larvæ or pupæ in the nest on September 3.

\section{Polistes poeyi Lep. [J. Bequaert]}

This Cuban wasp has been referred to in the literature as $P$. minor, but Dr. Bequaert tells me that, in his opinion, the true $P$. minor Beauv. does not occur in Cuba.

I collected 44 specimens of this species, most of which were taken at San José, where I also found a small nest on the under side of a large rock. I am not at all certain that the nest was built by Polistes poeyi, because the cells were empty and the comb apparently deserted. A female of this Polistes caught at San José on August 30, had captured a female trypetid fly, GEdicarena tetanops (Lw.), determined by Mr. Nathan Banks.

\section{Polistes major Beauv. [J. Bequaert]}

This species was nesting in exposed situations from three to six meters above the ground, on a cane lift near Arimao. The nests were attached to the under side of the steel girders by a single pedicel, and the combs were horizontal.

Two nests were secured, one on the sixth of September and another on the eleventh. The first was oblong in shape, about fourteen centimeters long, and nine wide. It contained 333 cells, but most of the peripheral cells had been recently constructed and were very shallow. The second nest was smaller and nearly round, with an average diameter of nine centimeters, and about 214 cells.

I captured 3 males and 20 females from the first nest, and 7 females from the second. I took the combs back 
to the laboratory, and by September 17, 14 males and 18 females had emerged from the first nest, and 10 females from the second. Since the second nest was younger, only females were produced. No parasites were bred from either nest, though two of the males had mites on the sixth sternite. When I returned to the site of the first nest on September 11, the wasps which I failed to catch on my first visit were building a new comb.

Beside the specimens from the nests, I collected a single female of this species at San José in the Trinidad Mountains on August 30.

\section{Polistes cubensis Lep. [J. Bequaert]}

This is the commonest species of Polistes around Soledad. I collected five nests from the bat caves at Guabairo, and one on the eastern side of the entrance to Cienfuegos Bay. The latter nest (see plate 1, figure 3) was hanging from a small tree about two meters above the ground. It resembles the nest of Polistes incertus, which was found in a similar location, but is one decimeter long and contains 309 cells. The back of the comb is nearly flat, not concave. I captured 46 females from this nest on September 4, and 33 females and one male emerged before September 17 . No parasites were bred from the nest, and none of the wasps were stylopized.

The nests from Guabairo were collected in sheltered places under limestone ledges in fairly thick woods. The one in plate 1 , figure 4 , is typical. The cells are intermediate in size between those of Polistes major and P. incertus. The back of the comb is concave, and the most recent cells form a sort of apron at the bottom. The base of the pedicel is a black, lichen-like attachment about a centimeter and a half in diameter. The following table will give an idea of the relative size and population of the five nests. The length of the comb is measured on the concave surface, but the width is measured in a straight line. The number of cells includes those which are unfinished. 
Nests of Polistes cubensis from Guabairo,

Central Soledad

\begin{tabular}{|c|c|c|c|c|c|}
\hline & $\begin{array}{l}\text { Nest } \\
\text { No. } 1\end{array}$ & $\begin{array}{l}\text { Nest } \\
\text { No. } 2\end{array}$ & $\begin{array}{l}\text { Nest } \\
\text { No. } 3\end{array}$ & $\begin{array}{l}\text { Nest } \\
\text { No. } 4\end{array}$ & $\begin{array}{l}\text { Nest } \\
\text { No. } 5\end{array}$ \\
\hline $\begin{array}{l}\text { Length of comb } \\
\text { in cms. }\end{array}$ & 19.5 & 14.5 & 8.0 & 11.5 & 19.0 \\
\hline $\begin{array}{l}\text { Width of comb } \\
\text { in cms. }\end{array}$ & 7.5 & 9.0 & 4.5 & 4.0 & 9.0 \\
\hline No. of cells & 573 & 447 & 130 & 197 & 570 \\
\hline Date collected & Aug. 20 & Aug. 20 & Sept. 7 & Sept. 7 & Sept. 7 \\
\hline $\begin{array}{l}\text { No. of wasps } \\
\text { taken with nest }\end{array}$ & 64 우 웅 & 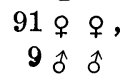 & $\begin{array}{l}\text { Nest } \\
\text { empty }\end{array}$ & $\begin{array}{l}?(\text { all } \\
\text { o } q)\end{array}$ & $\begin{array}{l}?(\text { all } \\
\text { 우 }\end{array}$ \\
\hline $\begin{array}{c}\text { No. of } \\
\text { which } \\
\text { befores } \\
\text { bept. 17 }\end{array}$ & 80 우 우 & 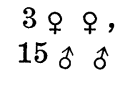 & - & 6 우 & $\begin{array}{l}10 \text { 우 } ᄋ, \\
18 \text { oे } \hat{\sigma}\end{array}$ \\
\hline
\end{tabular}

It is interesting to note that nest No. 1 failed to produce any males, though it was probably the oldest nest. Five females from nest No. 1 and four males from nest No. 2 were stylopized. Each contained a single parasite as follows: $3 \quad \& \quad \&$ with a parasite under the right side of the third tergite, and $2 \% \circ$ with a parasite under the left side of the third tergite; 2 of $\hat{o}$ with a parasite under the left side of the third tergite, one $\hat{o}$ with a parasite under the right side of the third tergite, and one $\hat{o}$ with a parasite under the left side of the third sternite. Two of the females from nests Nos. 4 and 5 (the wasps which I captured with these nests were not kept separate) had apparently been stylopized, and the parasites had emerged.

Nests Nos. 2, 4, and 5 were parasitized by Polistiphaga fulvescens (Cress.) [R. A. Cushman], originally described in the genus Mesostenus. One specimen emerged from nest No. 2 on August 21, and on September 16 two specimens emerged from nest No. 4, and seven specimens from nest No. 5. Polistiphaga fulva (Cress.) [J. Bequaert], a North American species of this genus, is parasitic on Polistes fuscatus (Fabr.) var. pallipes (Lep.) [J. Bequaert]. When collecting a nest of this wasp at Cold Spring Harbor, Long Island, New York, on September 6, 1929, I caught a single female of the parasite. Another 


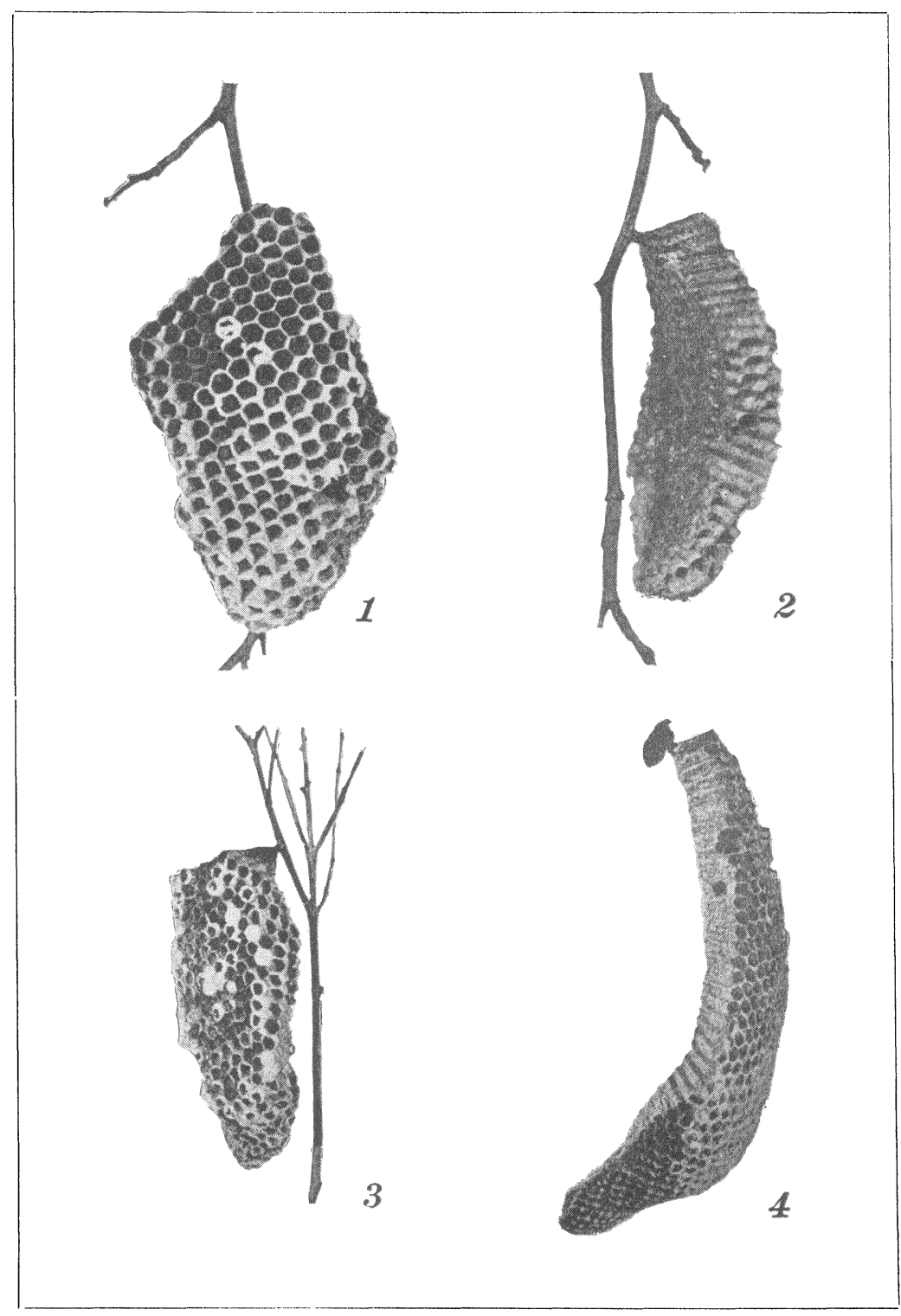

Dow-Cuban Wasps 
female emerged on the same day, and a third female on the 7th; two males emerged on the 8th. All five specimens apparently developed from a single larva of the Polistes.

\section{Explanation of Plate 1.}

Fig. 1. Nest of Polistes incertus Cress., from Punta de los Cocos, Cienfuegos, Cuba.

Fig. 2. The same, showing back of comb.

Fig. 3. Nest of Polistes cubensis Lep., from Punta Pasa Caballo, Cienfuegos.

Fig. 4. Nest of Polistes cubensis Lep., from Guabairo, Central Soledad, Cienfuegos.

\section{A NEW SPECIES OF DICAELUS FROM SOUTHERN FLORIDA}

BY H. C. FALL

Tyngsboro, Mass.

\section{Dicaelus darlingtoni n. sp.}

Size, form and general aspect similar to purpuratus. Form oblong, moderately elongate; body beneath and head black, prothorax and elytra with deep purpureo-violaceous lustre, becoming rarely slightly bluish, opaque. Head variable in size, the difference being largely sexual in nature; in several measured examples of each sex the ratio of its width to that of the thorax being about .67 in the female and .63 to .64 in the male.

Prothorax about three-fifths as long on the median line as the maximum width; sides convergent apically, typically perceptibly sinuate behind the middle, but varying to continuously arcuate and subparallel posteriorly, the base an- 

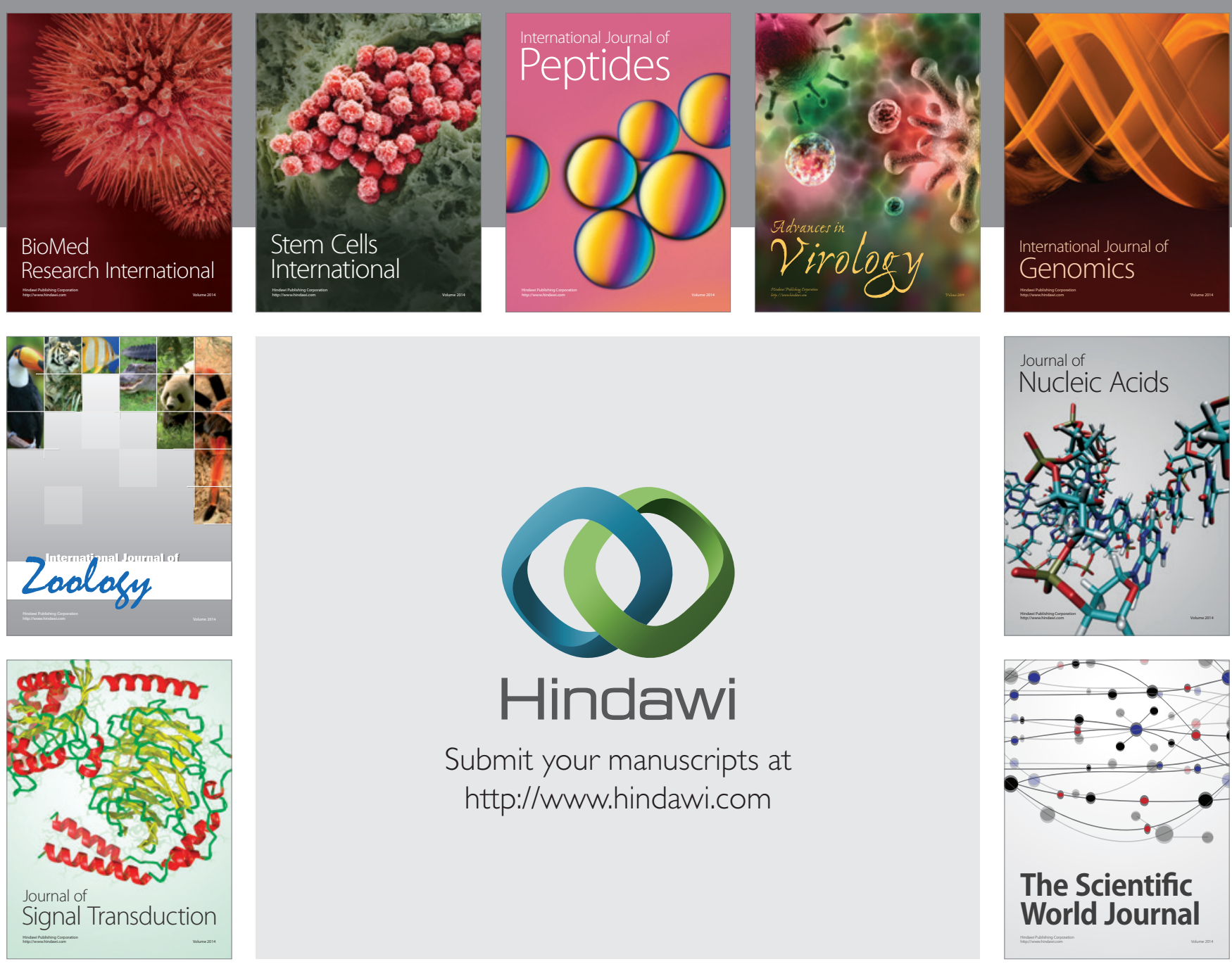

Submit your manuscripts at

http://www.hindawi.com
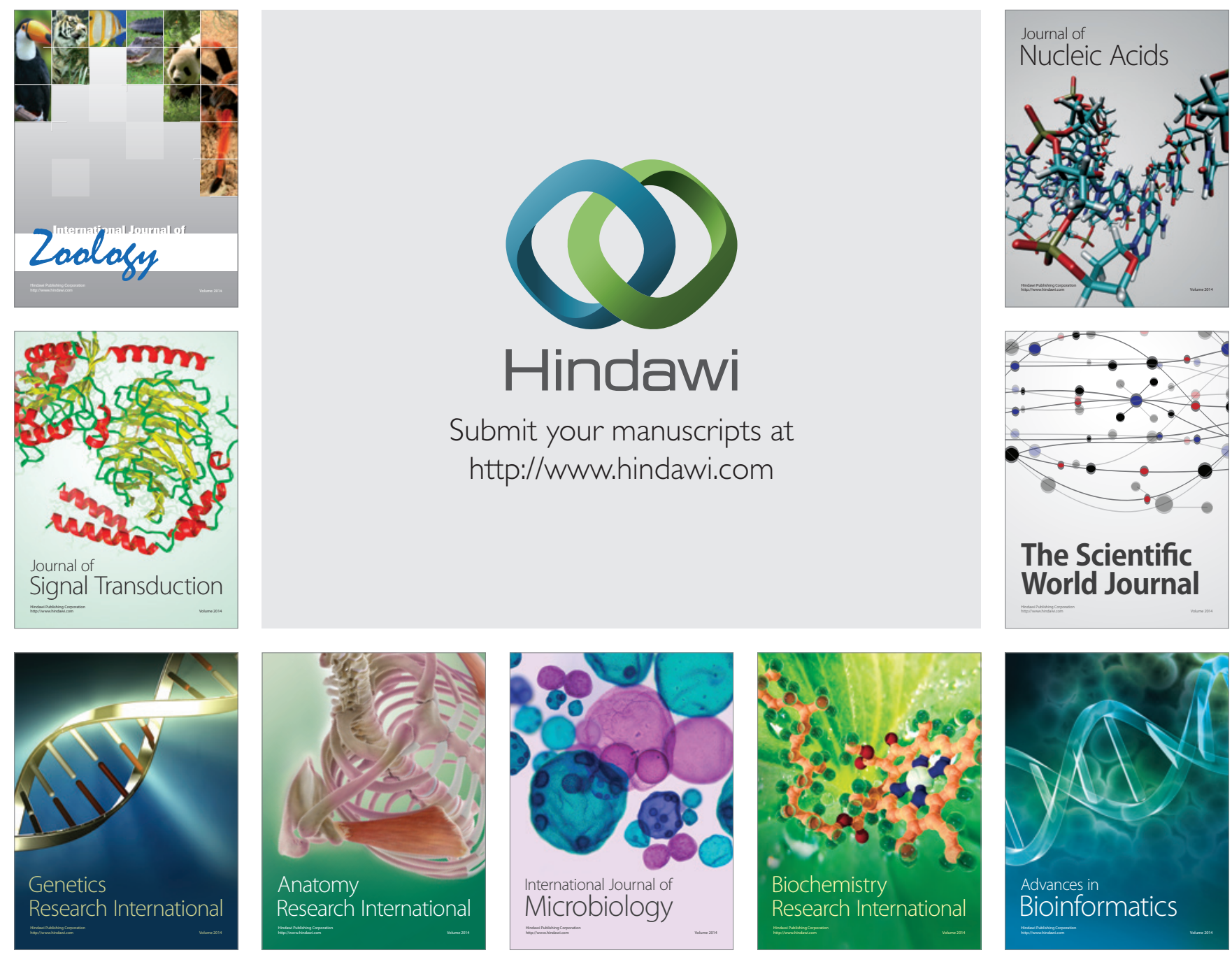

The Scientific World Journal
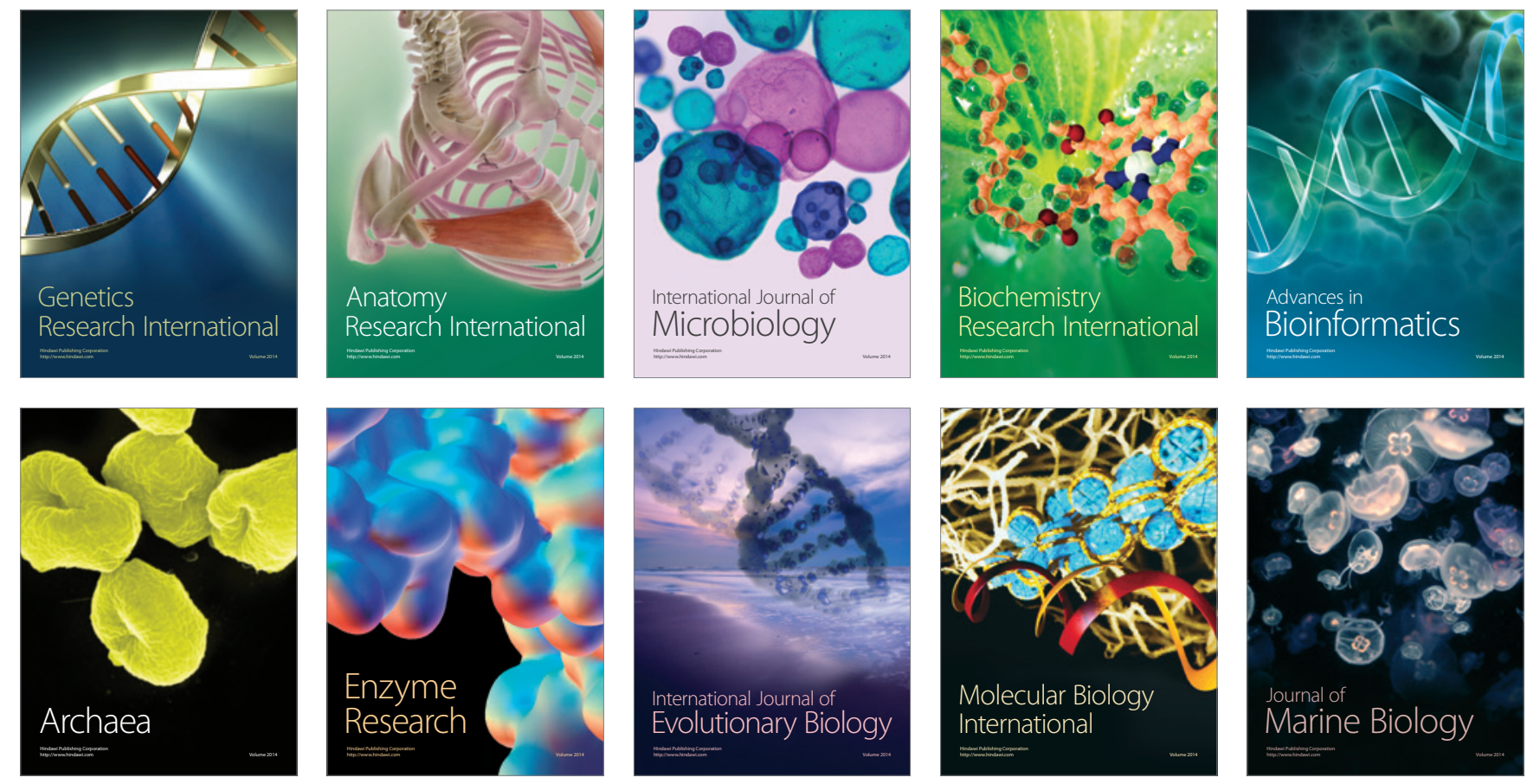